Hiroshi Goto MD, Kirk T. Benson MD, Hiroshi Katayama MD, Mayumi Tonooka, Lowell L. Tiilzer MD, Kasumi Arakawa MD PH D

\title{
Effect of high-dose of methylprednisolone on tourniquet ischaemia
}

High doses of carticosteroids have been found to have bereficial effects in various shock states. It has been well recognized that ischaemia is one of the important features in shock states. This prompted us to investigate the effect of high-dose methylprednisolone an tourniquet-induced ischaemia using mongrel dogs. After inflation of tourniquets to $600 \mathrm{mmHg}$ on each thigh of the hind legs, one leg received an intravenous infusion of methy'prednisolone, $3 \mathrm{mg} \cdot \mathrm{kg}^{-1}$ dissolved in $20 \mathrm{ml}$ of autologous blood. The other leg received the same amount of blood only, as a control. Duritg two hours of rourriquet time and until $30 \mathrm{~min}$ after tourniquet deflation, venous blood was sampled five limes from both hind legs for measurements of bload gas tensions $\left(\mathrm{P} \mathrm{O}_{2}, \mathrm{P}_{\vee} \mathrm{CO}_{2}\right)$ and $\mathrm{pH}$, lactic acid, crearimine kinase ( $\mathrm{CK}$ ). aspartate aminotransferase (AST) and lactate dehydrogenase (LDH). During tourniquet ischaemia, $\mathrm{PvO}_{2}$ and pH dropped and $\mathrm{PvCO}_{2}$, lactic acid, $\mathrm{CK}, \mathrm{AST}$ and $\mathrm{LDH}$ rose steadily and significantly in both groups of legs, indicating respiratory and metabolic acidosis, and muscle cell damage. However, those changes were significantly smaller in the methylprednisolonetreated legs. The beneficial effect of methylprednisolone could be atributed to its vasodilatory effect, cellular membrane stabilization and direct metabolic effect on skeletal muscle cells. Although the tourniquet-induced ischaemia in our study is slightly different from the clinical paradigm, the results suggest that high-dose methylprednisolone may provide a beneficial effect during tourniquet ischoemia.

\section{Key words}

ISCHAEMIA: tourniquet-induced; CORTICOSTEROIDS: methylprednisolone.

From the Departments of Anesthesiology and Pathology, University of Kansas Medical Center, Kansas City, Kansas.

Presented in part at the 1985 Annual Meeting of the American Society of Anesthesiologists, San Francisco, Califoria

Address correspondence to: Dr. Hiroshi Goto, Department of Anesthesiology, University of Kansas Medical Center, Kansas City, Kansas 66103.
Pneumatic toumiquets are widely used for limb surgery and facilitate intravenous regional anaesthesia. The extremity below the tourniquet becomes ischaemic, resulting in respiratory and metabolic acidosis, and skeletal cell damage. ${ }^{1.2}$ Biochemically, ischaemia and hypoxia are very similar to shock; a primary metabolic abnormality is a rapid and considerable reduction in the aerobic production of energy. ${ }^{3}$

Massive doses of corticosteroids, including methylprednisolone, have been found to have beneficial effects in different shock states. ${ }^{4-6}$ The mechanism for the beneficial effects has not been clearly determined, but severa! hypotheses have been proposed. These include a cell membrane stabilizing effect, ${ }^{7}$ reducing the liberation of vasoactive substances, ${ }^{8}$ a direct metabolic effect, ${ }^{9}$ and a vasodilative effect. ${ }^{10}$ The purpose of this study was to investigate, using a dog model, whether a corticosteroid such as methylprednisolone could attenuate the pathophysiological changes due to tourniquet-induced ischaemia.

\section{Methods}

Seven large mongrel dogs weighing $23-35 \mathrm{~kg}$ were used for this study. The dogs were anaesthetized with pentobarbitone $30 \mathrm{mg} \cdot \mathrm{kg}^{-1}$ IV. The trachea was intubated in order to assure an adequate airway, and then allowed to breathe spontaneously

IV catheters, 16 gauge, were placed in bath hind legs for venous access, and control venous blood samples werc drawn. Identical paediatric size toumiquets were applied to the thigh of both hind legs and connected via a $\mathrm{Y}$ connector to a Shook tourniquet unit. Two $20 \mathrm{ml}$ aliquots of venous blood were drawn from each dog's foreleg. Methylprednisolone, $3 \mathrm{mg} \cdot \mathrm{kg}^{-1}$ body weight, was dissolved in one of these samples of blood as a vehicle. The tourniquets were then simultaneously inflated to 600 muHg. Blood with methylprednisolone was then injected into one of the tourniquet-occluded legs. The other $20 \mathrm{ml}$ of autologous blood without methylprednisolone was injected into the opposite leg.

Venous blood samples were taken from both legs at 30 , 60 , and $120 \mathrm{~min}$ after toumiquet inflation. At $120 \mathrm{~min}$, after blood sample collection, the toumiquets were deflated, and samples were taken at 5 and 30 min after tourniquet release. 
TABLE I Venous blood pH and gas tensions (mean $\pm \mathrm{SE}$ )

\begin{tabular}{|c|c|c|c|c|c|c|c|}
\hline & \multirow[b]{2}{*}{ group } & \multirow[b]{2}{*}{$B V$} & \multicolumn{3}{|l|}{ Tourniquer on } & \multicolumn{2}{|l|}{ Tourniquet off } \\
\hline & & & 30 & 60 & 120 & 5 & $30(\mathrm{~min})$ \\
\hline $\mathrm{pH}$ & $\begin{array}{l}\text { Control } \\
\text { MP }\end{array}$ & $3.34 \pm 0.08$ & $\begin{array}{l}7.15 \pm 0.03 \div \\
7.21 \pm 0.04 * 8\end{array}$ & $\begin{array}{l}7.10 \pm 0.04 \dagger \\
7.17 \pm 0.05+\$\end{array}$ & $\begin{array}{l}6.95 \pm 0.05 t \\
7.07 \pm 0.06+5\end{array}$ & $\begin{array}{l}7.27 \pm 0.02 \\
7.27 \pm 0.02\end{array}$ & $\begin{array}{l}7.30 \pm 0.02 \\
7.28 \pm 0.02\end{array}$ \\
\hline $\begin{array}{l}\mathrm{PuO}_{2} \\
(\mathrm{mmHg})\end{array}$ & $\begin{array}{l}\text { Control } \\
\text { MP }\end{array}$ & $57.6 \pm 3.5$ & $\begin{array}{l}24.7 \pm 2.7^{*} \\
34.9 \pm 4.4^{*} \$\end{array}$ & $\begin{array}{l}23.3 \pm 3.7 \\
31.6 \pm 3.0+8\end{array}$ & $\begin{array}{l}20.3 \pm 2.4 \dagger \\
27.3 \pm 3.4 \dagger 8\end{array}$ & $\begin{array}{l}64.1 \pm 3.3 \\
61.7 \pm 3.7\end{array}$ & $\begin{array}{l}64.7 \pm 3.7 \\
61.1 \pm 3.7\end{array}$ \\
\hline $\begin{array}{l}\mathrm{PvCO}_{2} \\
(\mathrm{mmHg})\end{array}$ & $\begin{array}{l}\text { Control } \\
\text { MP }\end{array}$ & $46.0 \pm 1.5$ & $\begin{array}{l}69.4 \pm 4.6 \\
60.4 \pm 5.6^{-1} \$\end{array}$ & $\begin{array}{l}73.9 \pm 5.7 \dagger \\
64.1 \pm 6.6 \% \S\end{array}$ & $\begin{array}{l}98.1 \pm 9.2 \dagger \\
78.7=10.0 \dagger \xi\end{array}$ & $\begin{array}{l}42.4=2.2 \\
46.3=2.9\end{array}$ & $\begin{array}{l}43.4 \pm 2.3 \\
44.0 \pm 2.3\end{array}$ \\
\hline
\end{tabular}

BV, base line value; MP, Methylprednisolone.

* $(p<0.05), t(p<0.01)$ significant differences as compared to baseline values.

$\$(p<0.05)$. $\$(p<0.01)$ significant differences as compared to correspundirg values of control gruup.

Partial pressures of oxygen and carbon dioxide, and $\mathrm{pH}$ were measured with a Coming $178 \mathrm{pH}$ /gas analyzer. Lactic acid determinations were performed using a Dupont ACA III analyzer. Determination of enzymes including $\mathrm{CK}$, AST and LDH were performed utilizing an Abbott VP biochromatic analyzer. All enzyme activity was measured at $37^{\circ}$ and expressed in intemational units per litre $\left(\mathrm{IU} \cdot \mathrm{L}^{-1}\right)$. The data were analyzed using two-way analysis of variance for repeated measutes followed by Dunnett and Duncan tests with $p$ values $<0.05$ considered statistically significant.

\section{Results}

The control values for $\mathrm{PvO}_{2}, \mathrm{PvCO}_{2}$ and $\mathrm{pH}$ were $57.6 \pm$ $3.5 \mathrm{mmHg}$ (mean $\pm \mathrm{SE}$ ), $46.0 \pm 1.5 \mathrm{mmHg}$, and $7.34 \pm$ 0.08 respectively (Table $\mathrm{I}$ ). $\mathrm{PvO}_{2}$ and $\mathrm{pH}$ decreased, and $\mathrm{PvCO}_{2}$ increased steadily and significantly in both control and methylprednisolone-treated groups during the course of two hours of toumiquet ischaemia. In the methylprednisolone-treated legs, however, the decrease in $\mathrm{PvO}_{2}$ and $\mathrm{pH}$, and increase in $\mathrm{PvCO}_{2}$ were significantly less than in the control group at all times measured during courniquet occlusion $(p<0.01)$. Values retumed to control levels in both groups after the tourniquets were released.

Table II shows the changes of serum levels for CK, AST, and LDH. Their baseline values before tourniquet acclusion were: $\mathrm{CK} 66.1 \pm 18.0 \mathrm{IU} \cdot \mathrm{L}^{-1}$, AST $33.6 \pm 2.5$ IU $\cdot \mathrm{L}^{-1}$, and LDH $107.7 \pm 26.0 \mathrm{IU} \cdot \mathrm{L}^{-1}$, respectively. The increase in CK was significantly less $(p<0.05$ ) in the methylprednisolone-treated leg at $120 \mathrm{~min}$ of tourniquet occlusion. CK levels were further increased in both groups at $30 \mathrm{~min}$ after toumiquet deflation. AST levels rose significantly in both groups during tourniquet ischaemia. At 30 min of tourniquet occlusion the increase in AST was much less in the methylprednisolone-treated leg $(p<$ 0.01 ). Within five minutes after tourniquet release AST levels had returned to control levels in both groups. The increase in LDH levels was significantly less in the methylprednisolone-treated leg ( $p<0.01$ ) at all times measured during tourniquet occlusion. Both groups returned to baseline value within five minutes after the tourniquets were released.

Lactic acid increased significantly and steadily from baseline value of $6.6 \pm 1.3 \mathrm{mg} \cdot \mathrm{dl}^{-1}$ in both groups (Figure). The methylprednisolone-treated legs, however,

TABLE Il Serum enzymes

\begin{tabular}{|c|c|c|c|c|c|c|c|}
\hline & group & $B V$ & 30 & 60 & 120 & 5 & 30 (mir) \\
\hline CK & Control & & $113.1 \pm 28.2^{*}$ & $125.7 \pm 21.1^{*}$ & $170.7 \pm 31.68$ & $121.0 \pm 24.6^{*}$ & $194.5 \pm 50.9 \dagger$ \\
\hline$\left(\mathrm{IU} \cdot \mathrm{L}^{-1}\right)$ & MP & $66.1 \pm 18.0$ & $87.4 \pm 26.6$ & $111.0 \pm 28.9$ & $137.4 \pm 32.8 * \ddagger$ & $89.0 \pm 15.3 \ddagger$ & $182.9 \pm 45.5 t$ \\
\hline AST & Control & & $47.0 \pm 3.5 t$ & $46.6 \pm 2.2 \dagger$ & $51.6 \pm 2.9 \dagger$ & $31.3 \pm 1.6$ & $31.9 \pm 2.5$ \\
\hline LDH & Control & & $234.0 \pm 56.8^{*}$ & $272.4 \pm 57.4^{*}$ & $450.1 \pm 115.1 \dagger$ & $141.7 \pm 21.4$ & $143.0 \pm 30.6$ \\
\hline$\left(\mathrm{IU} \cdot \mathrm{L}^{-} \mathrm{l}\right)$ & MP & $107.7 \pm 26.0$ & $118.7 \pm 22.58$ & $190.7 \pm 40.1 \ddagger$ & $285.6=77.1 \mathrm{k} 8$ & $150.1 \pm 29.9$ & $143.3 \pm 18.9$ \\
\hline
\end{tabular}

EV, base line value; MP, Methylprednisolone.

" $(p<0.05), \dagger(p<0.01)$ significant differerces as compared to baseline values.

$\neq(p<0.05), \$(p<0.01)$ significant differences as compared to corresponding values of control group. 


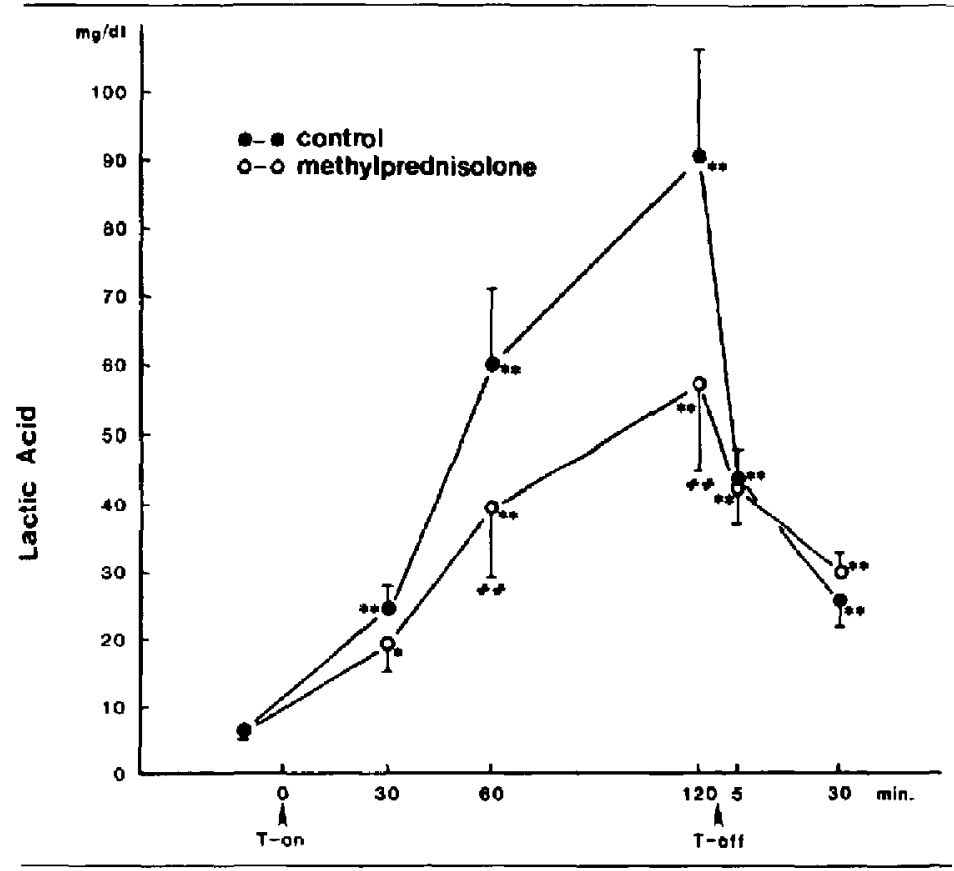

FIGURE Lactic acid levels (mean $\pm \$ E$ ). T-on and $T$-off indicate time of toumiquel inflation and deflation ${ }^{*} \mathrm{p}<0.05,{ }^{* *} \mathrm{p}<0.01$ as compared with baseline values before toumiquet inflation. \#\# $\mathrm{p}<0.01$ for intergroup comparison.

showed significantly less lactic acid production than the control group ( $p<0.01$ ) at 60 and $120 \mathrm{~min}$ of tourniquet occlusion. Lactic acid levels decreased precipitously in both groups after tourniquets were deflated; however, the levels rcmained significantly elevated.

\section{Discussion}

Our experimental model for tourniquet ischaemia is not exactly the same as the clinical paradigm. Clinically, the extremities are first exsanguinated with an Esmarch bandage and the tourniquet is inflated to a pressure above arterial pressure, producing a bloodless operative field. If a chinically relevant toumiquet ischaemia is employed, obviously multiple blood sampling is impossible. Therefore, each $20 \mathrm{ml}$ of autologous blood with or without methylprednisolone was injected into the hind leg veins after tourniquets around both thighs were inflated, making blood sampling possible during the ischaemic period. Clinically, the tourniquet is also used for intravenous regional anaesthesia in which usually $50 \mathrm{ml}$ of 0.5 per cent lidocaine is injected into the arm vein after the arm is exsanguinated and the tourniquet is inflated until blood flow ceases. Shortly after, analgesia is produced all over the surface of the arm below the tourniquet, indicating that lidocaine has spread evenly throughout the arm. Similarly, methylprednisolone dissolved in $20 \mathrm{ml}$ of blood as a vehicle was believed to be spread evenly through the dog's hindlimb below the tourniquet. The tourniquet was inflated to $600 \mathrm{mmHg}$, which was well above the clinically applied pressure, ensuring the almost complete arrest of circulation.

Ischaemia causes not only hypaxia but also cessation of substrate supply to tissues as well as accumulation of metabolites such as carbon dioxide and lactate. " Accordingly, the pathophysiological changes of toumiquet ischaemia include a fall in oxygen tension, respiratory as well as metabolic acidosis, and resulting cellular damage. ${ }^{1-2}$ If ischaemia lasts long enough to pass beyond the so-called "point of no return," cellular damage becomes irteversible, leading to cell death. ${ }^{3}$ The time of the point of no return for skeletal muscles subjected to ischaemia is much longer than that of other organs such as the brain and kidneys. In general, two hours of toumiquet time is clinically allowable for surgery. ${ }^{2}$ Among the glucocorticosteroids, methylprednisolone was selected for use in this study, since it has been found to pass through cell membranes rapidly. ${ }^{12}$ The usual dose of methylprednisolone is $30 \mathrm{mg} \cdot \mathrm{kg}^{-1}$ of body weight and up. ${ }^{13}$ We 
assumed that the weight of one hind limb is about ten per cent of the total body weight. Thus, methylprednisolone $3 \mathrm{mg} \cdot \mathrm{kg}^{-1}$ body weight was injected into a hind limb vein after the toumiquet was inflated. Since the control and experimental states were compared simultaneously in the same animal in our study, eror due to individual variability was eliminated.

It was not our purpose to investigate how glucocorticosteroids work. Thus, our study is phenomenologic like most studies in which the efficacy of glucocorticosteroids has been investigated in various pathophysiological conditions. However, demonstration of the beneficial effect of methylprednisolone in our study can be explained based on findings in studies by many researchers.

Immediately after tourniquet application, blood flow ceases and blood pressure drops essentially to zero. This haemodynamic change can initiate local release of vasoactive mediators. For example, noradrenaline is released at the end of the sympathetic nerve endings in the immediate vicinity of vascular smooth muscle, resulting in vasoconstriction. ${ }^{14}$ High doses of methylprednisolone have been found to inhibit the constrictur action of many vasoactive mediators, resulting in vasodilation. ${ }^{10,15}$ Therefore it is speculated that the degree of vasospasm, which is energy-requiring and would thereby consume oxygen, might have been less in the methylprednisolonetreated group. This may explain why the reduction of $\mathrm{PrO}_{2}$ and the increase in $\mathrm{PvCO}_{2}$ were significantly less in the drug-treated legs. As tourniquet time increases, accumulated metabolites and low $\mathrm{pH}$ cause dilatation of the arterial wall by inhibition of the contractility activity of the vascular smooth muscle cells. ${ }^{16}$

In addition to the vascular effect, glucocorticosteroids have been found to possess a direct cellular metabolic effect, ${ }^{9}$ although the mechanism is not known in detail. The study by Masters $e t$ al. ${ }^{17}$ indicated the beneficial effect of methylprednisolone, $40 \mathrm{mg} \cdot \mathrm{kg}^{-1}$, onl carbohydrate metabolism maintaining the generation of energyproducing substrates in acute myocardial ischacmia. Schumer and Nyhus ${ }^{18}$ showed evidence of decreased plasma lactic acid in their oligemic shock patients, demonstrating the protective metabolic effect of dexa. methasone. In our study, lactate production was significantly less in the methylprednisolone-treated group. This suggests that methylprednisolone possesses a direct beneficial metabolic effect on the skeletal muscle cells during tourniquet ischaemia.

Ischaemia-induced damage to the ccll membranc results in release of intracellular contents. Of these contents, it is release of enzymes, including CK, AST, and LDH that is particularly significant in the evaluation and confirmation of cell injury. ${ }^{19}$ Our study demonstrated skeletal muscle cell damage due to toumiquet ischaemia as evidenced by significant increases in these enzymes with toumiquet time. The methylprednisolone-treated groups, however, showed significantly smaller increases. How methylprednisolone protects the cel] is unclear, but our results would lend some support to the theory that corticosteroids have a stabilizing effect on cellular and subcellular membranes, which in turn reduces the release of intracellular contents. ${ }^{8,20,21}$ In addition, it has been shown that oxygen-free radicals play an important role in cellular injury in various ischaemic tissues including skeletal muscle. ${ }^{22}$ Fuenfer et al. ${ }^{23}$ demonstrated that a high dose of methylprednisolone can clearly inhibit the oxygen-free radical generation from leukocytes. Therefore, it can be speculated that in the tourniquet-induced ischaemic limb the oxygen-free radical system could have been inhibited in the methylprednisolone-treated limb, leading to a lesser degree of cellular injury with a resultant small increase in serum enzymes.

Reactive hyperemia from vasodilation by accumulation of anaerobic metabolites after toumiquet ischaemia is well established for skeletal muscle vessels. ${ }^{24}$ However, even increased blood flow to the ischaemic tissue does not guarantee the immediate retum of cellular function. After deflation of the toumiquet, some areas of skeletal muscle may still have disturbed microcirculation, called "'nonreflow" phenomenon. ${ }^{25}$ Therefore, cellular injury can persist 30 minutes to three hours after a one- to two-hour period of tourniquet ischaemia. ${ }^{26}$ This might explain the further increased CK levels which occurred after toumiquet release. The increase in CK levels may also be due to muscle injury under the tourniquet. In addition to the impaired microcirculation, reconstitution of aerobic metabolism from the anaerobic state is a complex process which may not always be completed properly after reflow occurs. ${ }^{3}$ This could be a reason why lactic acid levels in both groups were still significantly high at $30 \mathrm{~min}$ after toumiquet release.

In conclusion, the results of this study indicate that methylprednisolone provides a beneficial effect during tourniquet ischaemia. The mechanism of action for this effect remains unclear, however.

\section{References}

1 Solonen KA, Tarkkanen L, Norvanen S, Gordin R. Metabolic changes in the upper limb during tourniquet ischaemia. Acta Ortho Scand 1968; 39: 20-32.

2 Wilgis EFS. Observations on the effects of tourniquet ischemia. J Bone Joint Surg 1971; 53-A: 1343-6.

3 Kahng $M W$. Intermediary metabolism. In: Cowley RA, Trump BF (Eds). Pathophysiology of shock, anoxia, and ischemia. Baltimore/London: Williams \& Wilkins, 1982: 66-73.

4 Ferguson $J L$, Rosel OF, Bottoms GD. Dexamethasone treatments during hemorthagic shock. Blood pressure, 
tissue perfusion, and plasma enzymes. An J Vet Res 1978; 39: 817-24.

5 Schaefer CF, Bracken DJ, Wilson MF. The benefits of corricosteroid given after the onset of hypotension during endotoxin shock in the conscious tat. Adv Shock Res 1983; 10: 183-94.

6 Schumer W. Steroids in the treatment of clinical septic shock. Ann Surg 1976; 184: 333-9.

7 Hagland $U$. High doses of corticosteroids in the prevention of small intestinal mucosal damage in shock. Acta Chir Scand 1985; \$26 (Suppl): 66-72.

8 Lefer $A M$, Verriers $R L$. Role of corticosteroids in the treatment of circulatory collapse states. Clin Pharmacol Ther 1970; 11: 630-55.

9 Haljamae $H$. Metabolic effects of high dosc corticosteroids. Acta Chir Scand 1985; 526 (Suppl): 27-36.

10 Haggendal $E$, Lindfords $M$, Lundberg $D$. Hemodynamic effects of massive doses of hydrocortisone and the interaction with phenoxybenzamine in controlled hemornagic shock in the dog. Acta Anaesthesiol Scand 1976; 20: 185-95.

11 Merin RG. Myocardial metabolism. In: Kaplan JA (Ed). Candiac Anesthesia, Vol 2. Cardiovascular pharmacology. New York: Grune and Stration, 1983: 243-63.

12 Wilson JW. Cellular localization of ${ }^{3} \mathrm{H}$-labeled corticosteroids by electron microscopic autoradingraphy after hemorrhagic shock. In: Glenn TM (Ed). Steroid and Shock. Baltimore: University Park Press, 1974: 275-99.

13 Borg T, Gerdin B. Modig J. Prophylactic and delayed treatment with high-dose methylprednisolone in a porcine model of early ARDS induced by endotoxaemia. Acta Anaesthesiol Scand 1985; 29: 831-45.

14 Burton $A C$. Physiology and biophysics of the circulation. 2nd ed. Chicaga: Year Book Medical Yublishers, Inc. 1975: $20 \mathrm{~L}$.

15 Altura BM. Altura BT. The peripheral action of glucocorticoids and their relationship to protection in circulating shock. Pharmacol Ext Ther 1974; 190: 300-14.

16 Van Neuten JM. Vanhoutte PM. Improvement of tissue perfusion with inhibitors of calcium ion influx. Biochem Pharmacol 1980; 29: 479-81.

17 Masters TN, Harbold NB Jr, Hall DG et al. Beneficial metabolic effects of methylprednisolone sodium succinate in acute myocardial ischemia. Am J Cardiol 1976; 37: $557-63$

18 Schumer W, Nyhus LM. Corticosteroid effect on biochemical parameters of human oligemic shock. Arch Surg 1970 ; 10 : 405-8.

19 Kalso EA, Lalla ML, Rosenberg PH, Touminen $M K$, Santavirta S, Gripenberg J. Evaluation of the myotoxicity of bupivacaine in Bier Blocks - a biochemical and electron microscopic study. Anesth Analg 1983; 62: 796-801.

20 Clermont GH, Williams JS, Adams JT. Steroid effect on the release of the lysosomal enzyme acid phosphates in shock. Ann Surg 1974; 179: 917-21.

21 Horpacsy G, Nagy S, Baranakay T. Effect of watersolublc corticosteroid derivative on plasma levels of various intracellular enzymes in hemorrhagic shock. Enzyme Biol Clin 1970; 11: 234-5.

22 Kagan VE, Chorakova TO, Karagoin VP, Arkhipenko VV, Bilendo MV, Kozlov $Y P$. Disturbances of the $\mathrm{CA}^{++}$ transport enzyme system in membranes of the sarcoplasmic reticulurn caused by hydroperoxides of phospholipids and of fatty acids. Bull Exp Biol Med 1979; 87: 124-8.

23 Fuenfer MM, Carr EA, Polk HC. The effect of hydrocortisone on superoxide production by leukocytes. J Surg Res 1978; 27: 29-35.

24 Burton $A C$. Physiology and biophysics of the circulation. 2nd ed. Chicago: Year Book Medical Publishers, Inc. 1975: 211.

25 Strock $P E_{1}$ Majno $G$. Vascular responses to experimental toumiquet ischemia. Surg Gynec Obstet 1969; 129: 309-18.

26 Bumnell S. Bunnell's surgery of the hand. 5th ed. Phila* delphia, Toronto: J.B. Lippincott Company 1970: 141.

\section{Résumé}

Des doses élevées de corticostéroüdes ont été trouvées bénéfiques dans differents états de choc. II est bien reconnu que l'ischémie est un signe important des états de chor. Ceci nous a conduit à investiguer l'effet de doses élevées de mérhylpredMisolone sur l'ischêrmie induite par le tourniquet chez les chiens bâtards. Après inflation du tourniquet à $600 \mathrm{mmHg}$ sur chaque cuisse des pattes arrière, une patte a reça la perfusion intraveinuse de $3 \mathrm{mg} \cdot \mathrm{kg}^{-t}$ de méthylprednisolone dissout dans $20 \mathrm{ml}$ de sang autologue. L'autre patte a reçu la même quantité de sang et fut utilisée comme coniröle. Pendant deux heures du temps d'ischémie par tourniquet et 30 minutes après la déflation du tourniquet le sang veineux a été retiré à cing reprises des deux pattes pour fin de gazométrie $\left(\mathrm{PvO}_{2}, \mathrm{PvCO}_{2}\right) \mathrm{pH}$, acide lactique, créatine pattes pour fin de gazométrie $\left(\mathrm{PvO}_{2}, \mathrm{PvCO}_{2}\right)$ $\mathrm{pH}$, acide lactique, créatine kinase $(\mathrm{CK})$, aspartate aminotran. sférase (AST) et déhydrogénase lactique $(L D H)$. Durant l'is. chémie provoquée par le tourniquet, $\mathrm{Ka} \mathrm{PvO}_{2}$ et $\mathrm{pH}$ diminuèrent et la $\mathrm{PLCO}_{2}$, l'acide lactique, in $\mathrm{CK}$, l'AST et le $\mathrm{LDH}$ augmentèrent progressivement et significativement dans les deux groupes de pattes indiquant une acidose métabolique et respiratoire ainsi qu'une lésion de la cellule musculaire. Cependant, ces changements éraient significativement moindres pour les pattes trairées au méthylprednisolone. L'effet bénéfique de la méthylprednisolone pourra être attribué à son effet vasodilatateur, son effet stabilisateur de la membrane cellulaire et un effet métabolique direct sur la cellule musculaire squelettique. Méme si le temps d'ischémie induit par le tourniqugt dans notre étude est légèrement différent de la clinique, les résultats suggèrent que les doses élevées de méthylprednisotone peuvent amener un effet bénéfique sur l"ischèmie provoquée par le sourniquet. 